\title{
The Heat Exchange Mathematical Model of Fire in Cable Tunnel Adequacy Research
}

\author{
Oleksandr Nuianzin $^{1 *}$, Taras Samchenko ${ }^{2}$, Serhii Kasiarum ${ }^{1}$, Kostiantyn Hryhorenko ${ }^{1}$, Mykola Kryshtal ${ }^{1}$ \\ ${ }^{1}$ Cherkassy institute of Fire Safety named after Chernobyl Heroes \\ National University of Civil Protection of Ukraine \\ ${ }^{2}$ Ukrainian Civil Protection Research Institute \\ *Corresponding author E-mail: nuyanzin@i.ua
}

\begin{abstract}
According to the results of the conducted studies, the adequacy of the mathematical models of cable tunnels for their further use in the study of the temperature regime of the fire was checked. For this purpose, full-scale tests and findings about the dynamics of temperature change in cable tunnels with known geometrical parameters and fire load were conducted at the experimental test site of the Ukrainian Civil Protection Research Institute (Kyiv).

In one of the CFD software systems, a mathematical model of a cable tunnel similar to the actual one was created. A computational experiment was conducted. Based on the results of the computational experiment and field tests, the criteria for adequacy (Student's tcriterion, Cochran's Q-criterion, Fisher's F-criterion) and the relative error of the experiments were calculated. On the basis of the analysis, the adequacy of the used mathematical models was studied.

In this article, further development of the use of computational experiments to study the heat and mass exchange processes during fires in cable tunnels.
\end{abstract}

Keywords: Cable tunnel; computational experiment; criteria of adequacy; field experiment; temperature regime of fire.

\section{Introduction}

The problem of fire safety of electric cables existed in the past and continues to exist in the present. Significantly, the increase in the number of fires in cable communications was due to an increase in the number of cables used for control and management of electrical equipment in modern industries, as well as the use of general industrial applications for soil layers without additional measures for their fire protection. In addition, the development and improvement of telecommunication networks of Ukraine's general use is carried out in accordance with the Concept of the development of telecommunications in Ukraine with the application of the latest telecommunication technologies in line with international standards, taking into account the technological integrity of all networks and telecommunication facilities, improving efficiency and sustainability of operation. When designing and constructing cable networks, in particular cable tunnels building must be complied to ensure that the fire resistance of the construction structures of the cable tunnels comply in case of fire.

Cable products are constantly evolving and improving.

For tests on the fire resistance of building structures of cable tunnels, a standard temperature regime of fire is used which may not correspond to fire mode in a real cable tunnel.

Investigation of the temperature regime of the fire is a topical issue, as the cable tunnels are notable for different geometric configuration, the type of cables laid in them, fire load and aerodynamic characteristics. This can lead to the fact that the temperature of the fire in such tunnels may differ from both the standard and each other. In this case, it is not possible to guarantee the conform- ity of the limits of fire resistance of the tested constructions to the current norms. In this case, the safety of people and property can be significantly reduced during fires in cable tunnels.

In order not to conduct expensive tests for the study of the subject, it is possible to carry out such studies based on the results of computational experiments. Modern software for modeling of thermal processes by means of computer gas dynamics (CFD) allows to take into account all necessary parameters of the studied processes and to study the influence of geometrical and structural characteristics of the furnace for tests of reinforced concrete structures on the quality of the data obtained.

\section{The Analysis of Literary Data}

Many scientists were and are engaged in investigations of temperature regimes, in particular, in the tunnels. For example V. M. Roitman in his study [1] proposed the temperature regime of the fire in tunnels.

The work [2-4] studied the dynamics of the development of fires in cable structures and the behavior of building structures in case of high temperatures. both real and computational experiments were applied.

In work [5] it is established that the width of the tunnel has little effect on the rate of burnout of the fire load. The work [6] describes a group of full-scale experiments. The temperature distribution in tunnels with different ventilation conditions was measured. The numerical simulation [7] analyzed the causes of fires in tunnels. The work [8] is devoted to the analysis of the parameters of burning rate of insulation of a PVC cable. The linear propagation speed of fire at different types of cable laying was considered. 
Despite the practical significance of such results, there is no evidence of verification of mathematical models in cable tunnels based on experimental data. In the previous work [9], the methodology for conducting an experiment on modeling a fire in a cable tunnel, which was developed on the basis of normative documents, was substantiated. The process of conduction is described and the results of the experiment on determining the temperature regime of a fire in a cable tunnel according to the developed method are presented. The obtained data became the basis for the verification of computer models of fires in cable tunnels and the determination of the temperature regime of fire for testing fire resistance of building structures of cable tunnels.

\section{The Purpose and Objectives of the Research}

The purpose of the work is to verify the adequacy of CFD-fire design models in cable tunnels created in the Fire Dynamics Simulator 6.2 software based on experimental data for their further use in the study of the effect of fire load and design characteristics of cable tunnels on the temperature regime of the fire.

To achieve the purpose, the following tasks are addressed:

1. Calculating the criteria for the adequacy of mathematical models of fire in cable tunnels created in the Fire Dynamics Simulator 6.2 software based on experimental data (Student's t-criterion, Cochran's Q-criterion, Fischer's F-criterion).

2. Calculating the relative error of mathematical modeling results from experimental data.

3. Concluding on the efficiency of thermal process simulation for conducting further studies of temperature regimes of fire in cable tunnels.

\section{Presentation of the Main Research Material with Full Justification of the Results}

\subsection{The Results of the Full-scale Experiment}

The experimental research was conducted at the testing ground of the Ukrainian Civil Protection Research Institute (Kyiv) using the method described in [9]. Two experiments were conducted for correlation of results, each with duration of 30 minutes.

The temperature-time dependence in the cable tunnel on the results of experimental studies on each of the 30 installed thermocouples is shown in Fig. 1.

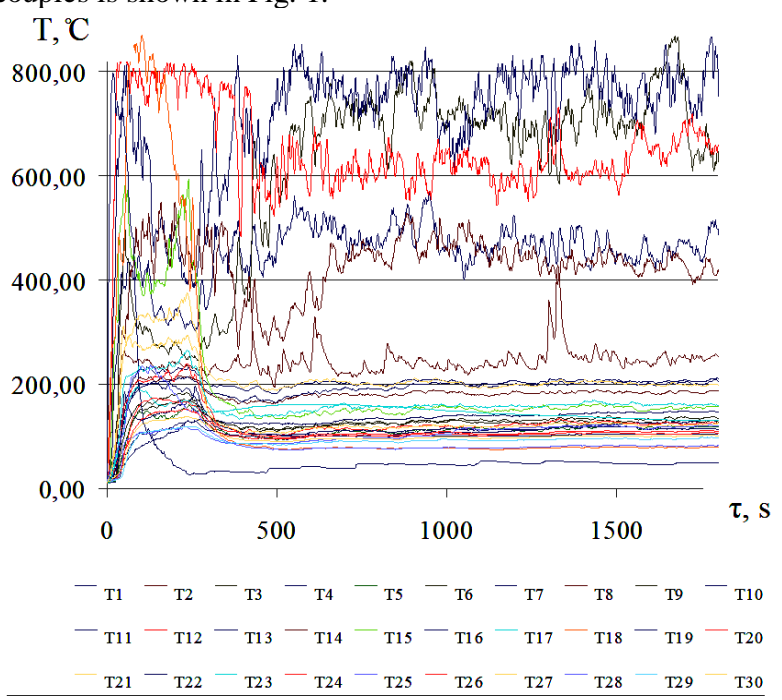

Fig. 1: The temperature-time dependence in the cable tunnel on the results of experimental studies on each of the 30 installed thermocouples (see Figure 2).

Diagram of thermocouple arrangement in a cable tunnel is shown in Fig. 2.

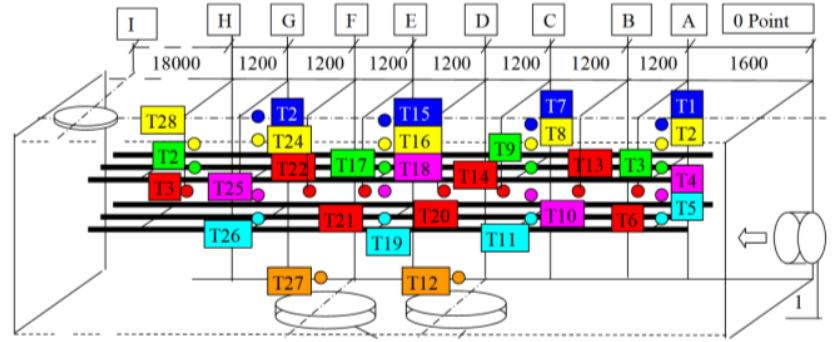

a

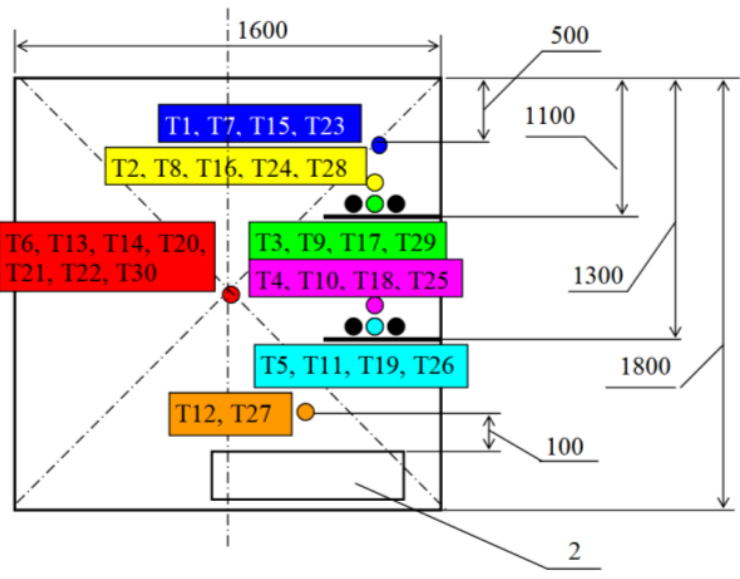

b

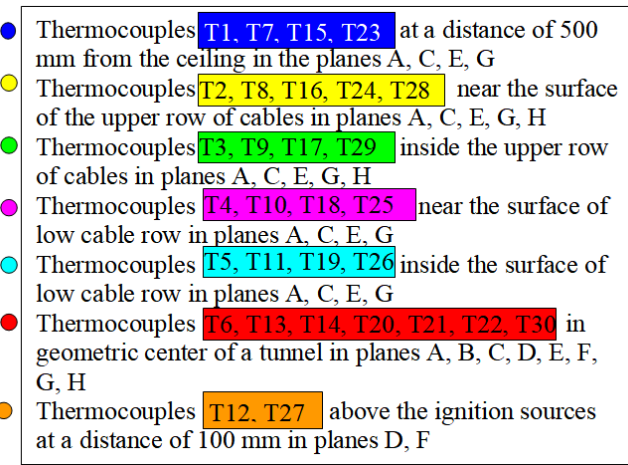

c

Fig. 2: Schematic of thermocouples arrangement in a cable tunnel. Row 1 of cable bundles less than $796 \mathrm{~kg}$ - above $791 \mathrm{~kg}$; row 2 of cable bundles less than $864 \mathrm{~kg}$ - above $861 \mathrm{~kg}$ : a - view along the length of the tunnel, $\mathrm{b}$ - view of the cross section of the tunnel, $\mathrm{c}$ - thermocouple identification.

Analysing the obtained graphs of temperature in the cable tunnel, we can state that the highest temperature is observed in the area of the fire cell near the cables. It varies from 700 to $1000^{\circ} \mathrm{C}$, depending on the location of the control. Thermal energy propagates more intensively towards the exit opening of combustion products. The temperature varies from 300 to $500^{\circ} \mathrm{C}$. In the zone between the fire cell and the seat of the air support, the temperature is within the range of $80-200{ }^{\circ} \mathrm{C}$ (Fig. 1).

\subsection{Calculating Experiment}

For a calculating experiment using the created mathematical model of the cable tunnel for testing, the following sequence of settlement procedures is used.

1. Using CAD software, a geometric configuration of the cable tunnel of the required size is created. Inside, models of cables, steel corners, openings for the output of combustion products and air space are created. The geometric model is imported into the environment of the FDS settlement system.

2. The initial modeling parameters are presented, which are impossible to change during the calculation: the initial environmental temperature, the air support on one side of the tunnel, the required time of fire. 
3. The combustion process in the middle part of the tunnel is initiated directly under the cables. For this purpose, a fire cube cell with the size $0.236 \mathrm{~m}^{3}$ is simulated.

4. During the calculation, the temperature monitoring of the corresponding points in the tunnel and the temperature gradient is monitored online.

The view of the cable tunnel mesh model used for the computational experiment is shown in Fig. 3.

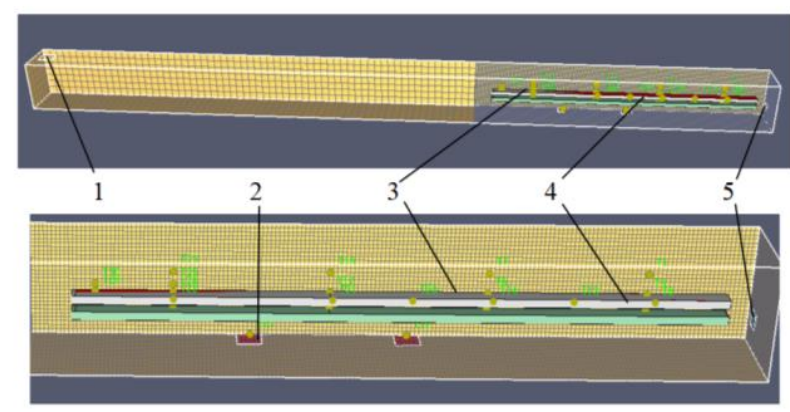

Fig. 3: The view of the cable tunnel model used for the computational experiment: 1 - a hole of exit of combustion products; 2 - a fire cell; 3 - a metal corner; 4 - cables; 5 - air support zone.

In order to control the temperature regime, with the help of the FDS computer system with 30 control points corresponding to the locations of the thermocouples during the natural experiment (see fig. 1) were created (shown in Fig. 4).

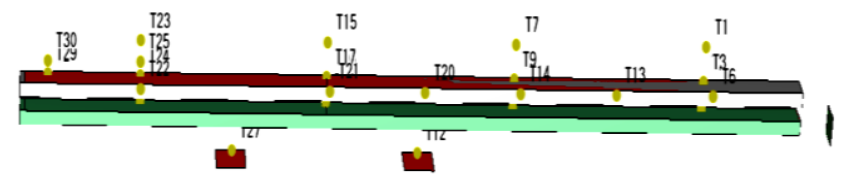

Fig. 4: The scheme of location of temperature control points in a cable tunnel: T1 - T30 - control points (fig. 1).

For the visibility of the process of heating the space of the cable tunnel during the calculation experiment in computer models, planes in which the temperature value is visualized with the help of colors ("temperature flushing") were created. Temperature gradient in the model space of the cable tunnel is shown in Fig. 5.

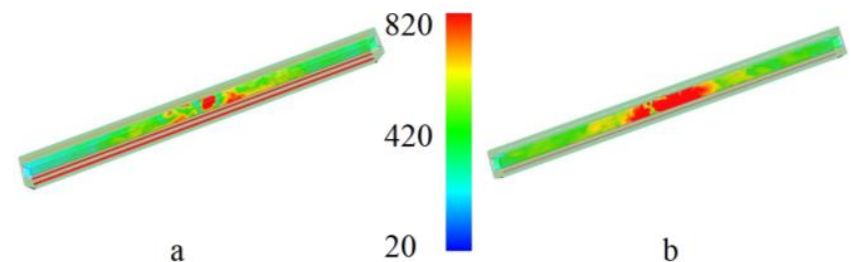

Fig. 5: Temperature gradient in the model space of the cable tunnel: $a-5$ minutes, $b-30$ minutes.

Taking into account the temperature distribution shown in Fig. 5, the cable tunnels can be conventionally divided into 3 zones: a fire cell, between a fire cell and an exit opening of combustion products, between the fire cell and the air space.

After completion of the computational experiment, the temperature data for each control site for the verification were obtained.

In Fig. 6 the graphs of the average temperature in different parts of the cable tunnel during the calculation experiment are constructed.

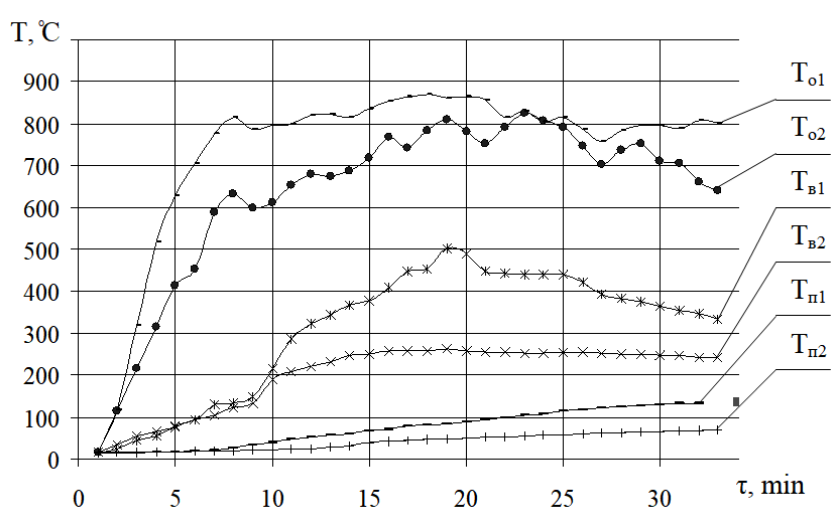

Fig. 6: Average temperature in 3 zones of the cable tunnel: $\mathrm{T}_{\mathrm{o} 1}-$ in the upper part of the tunnel zone of the fire cell; $\mathrm{T}_{\mathrm{o} 2}-$ at the bottom of the tunnel zone of the fire cell; $\mathrm{T}_{\mathrm{B} 1}$ - the upper part of the tunnel zone between the fire cell and the hole for exit of combustion products; $\mathrm{T}_{\mathrm{B} 2}-$ at the bottom of the tunnel zone between the fire center and the hole for exit of combustion products; $\mathrm{T}_{\mathrm{n} 1}-$ in the upper part of the tunnel, the zone between the fire cell and the place of the air support; $\mathrm{T}_{\mathrm{n} 2}-$ in the lower part of the tunnel zone between the center of fire and the place of air support.

\subsection{Checking the Adequacy of the Mathematical Model}

The adequacy check is carried out on the basis of experimental information obtained as a result of the tests [9].

The following adequacy criteria were used to verify the adequacy of the simulation results:

- Fisher's F-criterion. Using Fisher's criterion, it is possible to test the hypothesis of the equality of general dispersions, temperature variations at each minute of the test.

$F=\frac{S_{x y}^{2}}{S_{y}^{2}}$,

where $S_{x y}^{2}$ - variance of adequacy, $S_{y}^{2}-$ variability of reproducibility.

The dispersion of adequacy was calculated as the deviation between the estimated and experimental data for each of the thermocouples set during the field experiment and its corresponding temperature measurement point in the mathematical model.

In the created model there are 30 places of temperature measurement, during the experiment of thermocouples -30 . The data of each of the thermocouples of the calculation were compared in turn with the thermocouples of the experiment. Thus 30 values of the dispersion of adequacy were obtained.

$S_{x y}^{2}=\frac{\sum_{i=1}^{n}\left(x_{i}-y_{i}\right)^{2}}{n}$,

where $\mathrm{n}-$ the number of temperature measurements, $y_{i}$ - value of the criterion in modeling, $x_{i}$-criterion value when tested.

Dispersion of reproducibility was calculated as a deviation between the results of two field experiments, taking into account the experimental error [10].

$S_{y}^{2}=\frac{1}{n} \sum_{i=1}^{n}\left(\left|y_{i}-\bar{y}\right|+15\right)^{2}$,

where $\mathrm{n}-$ the number of temperature measurements, $\bar{y}$ - the temperature of the second natural experiment, $y_{i}$ - the temperature of the first natural experiment. 
Table 1: Parameters of the Dispersion of the Results of Mathematical Modeling of the Process of Heat Exchange during a Fire in a Cable Tunnel from Experimental Data.

\begin{tabular}{|c|c|c|c|c|c|c|c|}
\hline $\begin{array}{c}\text { Thermocouple } \\
\text { zone(fig. 2, } \\
\text { fig. 4) }\end{array}$ & 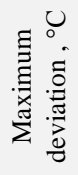 & 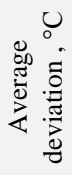 & 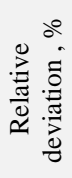 & 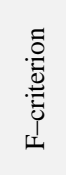 & 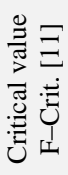 & : & 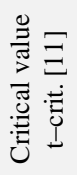 \\
\hline $\mathrm{T}_{1}$ & 54.3 & 14.1 & 10.4 & 2.42 & \multirow{31}{*}{4.00} & 1.81 & \multirow{31}{*}{2.75} \\
\hline $\mathrm{T}_{2}$ & 52.1 & 10.3 & 9.9 & 2.27 & & 1.68 & \\
\hline $\mathrm{T}_{3}$ & 45.5 & 17.8 & 9.8 & 2.08 & & 1.80 & \\
\hline $\mathrm{T}_{4}$ & 45.6 & 17.9 & 11.6 & 2.43 & & 1.93 & \\
\hline $\mathrm{T}_{5}$ & 20.2 & 6.1 & 7.3 & 1.84 & & 1.23 & \\
\hline $\mathrm{T}_{6}$ & 39.7 & 19.0 & 11.5 & 2.53 & & 2.14 & \\
\hline $\mathrm{T}_{7}$ & 49.4 & 17.2 & 11.7 & 2.77 & & 1.95 & \\
\hline $\mathrm{T}_{8}$ & 46.3 & 14.9 & 9.8 & 2.17 & & 1.69 & \\
\hline $\mathrm{T}_{9}$ & 50.2 & 13.1 & 8.1 & 1.98 & & 1.21 & \\
\hline $\mathrm{T}_{10}$ & 59.5 & 20.2 & 10.1 & 2.06 & & 1.78 & \\
\hline $\mathrm{T}_{11}$ & 51.1 & 21.0 & 10.0 & 2.04 & & 1.78 & \\
\hline $\mathrm{T}_{12}$ & 81.9 & 19.7 & 6.8 & 1.44 & & 1.01 & \\
\hline $\mathrm{T}_{13}$ & 45.8 & 18.4 & 7.9 & 1.42 & & 1.20 & \\
\hline $\mathrm{T}_{14}$ & 74.1 & 25.9 & 7.3 & 1.45 & & 1.18 & \\
\hline $\mathrm{T}_{15}$ & 131.2 & 50.3 & 6.4 & 1.42 & & 1.18 & \\
\hline$T_{16}$ & 139.7 & 48.1 & 6.4 & 1.35 & & 1.17 & \\
\hline $\mathrm{T}_{17}$ & 132.8 & 48.0 & 6.5 & 1.41 & & 1.14 & \\
\hline $\mathrm{T}_{18}$ & 109.2 & 46.4 & 5.7 & 1.32 & & 1.15 & \\
\hline $\mathrm{T}_{19}$ & 122.5 & 57.8 & 7.9 & 1.48 & & 1.19 & \\
\hline $\mathrm{T}_{20}$ & 92.9 & 45.4 & 8.2 & 1.54 & & 1.21 & \\
\hline $\mathrm{T}_{21}$ & 91.0 & 36.1 & 6.7 & 1.50 & & 1.17 & \\
\hline $\mathrm{T}_{22}$ & 98.8 & 36.8 & 7.0 & 1.56 & & 1.18 & \\
\hline $\mathrm{T}_{23}$ & 82.3 & 36.0 & 8.6 & 1.69 & & 1.24 & \\
\hline $\mathrm{T}_{24}$ & 72.1 & 32.8 & 6.6 & 1.47 & & 1.20 & \\
\hline $\mathrm{T}_{25}$ & 75.4 & 43.7 & 8.7 & 1.66 & & 1.23 & \\
\hline$T_{26}$ & 70.6 & 40.2 & 8.4 & 1.62 & & 1.22 & \\
\hline$T_{27}$ & 100.7 & 61.4 & 7.0 & 1.58 & & 1.24 & \\
\hline $\mathrm{T}_{28}$ & 28.9 & 15.6 & 8.6 & 1.69 & & 1.11 & \\
\hline $\mathrm{T}_{29}$ & 24.9 & 13.9 & 13.5 & 3.45 & & 2.53 & \\
\hline $\mathrm{T}_{30}$ & 28.0 & 10.2 & 8.8 & 1.70 & & 1.09 & \\
\hline Average value & 70.6 & 28.61 & 8.58 & 1.78 & & 1.84 & \\
\hline
\end{tabular}

Thus, we alternate 30 values of the dispersion of adequacy, compare with the variability of reproducibility and calculate Fisher's criterion.

All results are summarized in Table 1.

- Student's t-criterion is used to compare the results of real and computational experiments:

$$
t=\frac{\bar{y}_{1}-\overline{y_{2}}}{\sqrt{\left(n_{1}-1\right) \cdot S_{1}^{2}+\left(n_{2}-1\right) \cdot S_{2}^{2}}} \cdot \sqrt{\frac{n_{1} \cdot n_{2} \cdot\left(n_{1}+n_{2}-2\right)}{n_{1}+n_{2}}}
$$

$$
\bar{y}_{1,2}=\frac{1}{n} \sum_{i=1}^{n} y_{i}
$$

where $S_{1}^{2}, S_{2}^{2}$ - estimates of the dispersion of the real and calculation experiment were calculated similarly to the Fisher's criterion.

Thus when calculating the dispersion of the reproducibility, as the deviation of the calculated temperature of the space directly near the simulated thermocouple and the readings of the simulated thermocouple, taking into account the experimental error 30 values of the criterion were obtained $[9,10]$.

The results are summarized in Table 1.

- Q - Cochran's Q criterion (estimation of emissions and quasi emissions)

$$
Q=\frac{S_{\max }^{2}}{\sum_{i=1}^{p} S_{i}^{2}}
$$

where $S_{\max }-$ the highest average deviation of the test results.
Q-criterion is used when comparing three or more samples of the same volume. The dispersion between two natural experiments and a calculation one at the location of each thermocouple was compared. 30 criteria values were obtained. Emissions and quasi emissions are not detected.

Analysing the comparison of the dispersion of the results of the mathematical modelling of the heat transfer process during a fire in a cable tunnel and experimental data (Table 1), it can be stated that none of the values of the criteria of adequacy exceeds the permissible values, the relative deviation is $8.58 \%$, which shows the effectiveness of the simulation of thermal processes for conducting further studies of temperature regime of fire in cable tunnels.

\section{Conclusion}

In this study, the adequacy of mathematical models of cable tunnels for their further use in the study of the temperature regime of the fire with the use of CFD Fire Dynamics Simulator 6.2 software system was checked and the efficiency of thermal process simulation for further studies of the temperature regime of fire in cable tunnels was proved. To achieve the goal, the following tasks are accomplished:

1. The mathematical model of the cable tunnel, which is analogous to the actual experiment carried out earlier was created [9]. A computational experiment was conducted.

2. Based on the results of the computational experiment and natural experiments, the criteria for adequacy (Student's tcriterion, Cochran's Q-criterion, Fischer criterion) were calculated. None of the criteria for the adequacy criteria exceeds the permissible values. At critical values, Fisher's F-criterion is 4.00 Student's t-criterion is 2.75, Cochran's Q-criterion is 0.88 [11], and their average values are: $1.78 ; 1.84$ and 0.88 respectively, and the maximum value did not exceed the critical one.

3 . The relative deviation of the results of mathematical modeling from the experimental data was calculated. It is $8.58 \%$.

4. The results of the research show the effectiveness of the simulation of thermal processes for conducting further studies of temperature regimes of fire in cable tunnels.

\section{References}

[1] Roytman V. M., Inzhenernyye resheniya po otsenke ognestoykosti proyektiruyemykh i rekonstruiruyemykh zdaniy, Moscow: Pozhnauka, (2001), pp.14-16

[2] Niu Y., \& Li W., "Simulation Study on Value of Cable Fire in the Cable Tunnel", Procedia Engineering, 43, (2012). pp.569-573, https://doi.org/10.1016/j.proeng.2012.08.100

[3] Nekora O., Slovynsky V., Pozdieiev S., "The research of bearing capacity of reinforced concrete beam with use combined experimental-computational method", MATEC Web of Conferences Vol.116, (2017), pp.02024, https://doi.org/10.1051/matecconf/201711602024

[4] Zhao Y.C., Zhu G.Q., Gao Y.J., "Experimental Study on Smoke Temperature Distribution under Different Power Conditions in Utility Tunnel", Case Studies in Thermal Engineering, No.12, (2018), pp.69-76, https://doi.org/10.1016/j.csite.2018.03.002.

[5] Ji J. et al., "Influence of aspect ratio of tunnel on smoke temperature distribution under ceiling in near field of fire source", Applied Thermal Engineering, Vol.106, (2016), pp.1094-1102, https://doi.org/10.1016/j.applthermaleng.2016.06.086

[6] Tian X. et al., "Full-scale tunnel fire experimental study of fireinduced smoke temperature profiles with methanol-gasoline blends", Applied Thermal Engineering, Vol.116, (2017), pp.233243, https://doi.org/10.1016/j.applthermaleng.2017.01.099

[7] Modic J., "Fire simulation in road tunnels", Tunnelling and underground space technology, Vol.18, No.5, (2003), pp.525-530, https://doi.org/10.1016/S0886-7798(03)00069-5

[8] Vaari J. et al., Numerical simulations on the performance of waterbased fire suppression systems, VTT Technol, (2012), 54p.

[9] Nuyanzin O., Pozdieiev S., Hora V., Shvydenko A., Samchenko T., "Cable tunnels temperature fire mode experimental study", 
Eastern European Journal of Enterprise Technologies, No.3, (2018), pp.31-37.

[10] Pozdieiev S., Nuianzin O., Sidnei S., Shchipets S., "Computational study of bearing walls fire resistance tests efficiency using different combustion furnaces configurations", MATEC Web of Conferences,
Vol.116
p.02027,
(2017),

https://doi.org/10.1051/matecconf/201711602027

[11] Kaptsov I.I., Romashko O.V., Gaponova L. V. and others, Metodicheskiye ukazaniya $k$ nauchno-issledovatel'skoy praktiki po distsipline "Organizatsiya nauchnykh issledovaniy". Statisticheskiye metody. Analiz i oformleniye nauchnykh issledovaniy, Kharkiv: KhNAHKh, (2009), 59p. 